\title{
New record of monogeneans (Platyhelminthes: Monogenea) infecting some marine fishes from the Peruvian coastal zone
}

\author{
Nuevos registros de monogeneos (Platyhelminthes: Monogenea) infectando algunos \\ peces marinos del litoral peruano
}

\author{
Aline Carvalho-Azevedo ${ }^{1}$ \\ aline.c.a@hotmail.com \\ Eva G. Huancachoque ${ }^{2}$ \\ evagloria6694@gmail.com \\ Ivette Cuellar ${ }^{2}$ \\ ivette17110@gmail.com \\ Gloria M. Sáez ${ }^{2}$ \\ https://orcid.org/0000-0001-9093-0065 \\ gsaez@unfv.edu.pe \\ Celso L. Cruces ${ }^{2,3}$ \\ https://orcid.org/0000-0003-1044-0862 \\ cruces.ccl10@gmail.com

\section{Jhon D. Chero ${ }^{2,3}$ \\ https://orcid.org/0000-0003-3633-1365 \\ Cristhian-5645@hotmail.com \\ José L. Luque* 4 \\ https://orcid.org/0000-0003-3515-1127 \\ luqueufrrj@gmail.com \\ *Corresponding author}

1 Curso de Medicina Veterinária da Universidade Federal Rural do Rio de Janeiro, BR 465, Km 7, CEP 23890-000, Seropédica, Rio de Janeiro, Brazil.

2 Laboratorio de Parasitología General y Especializada, Facultad de Ciencias Naturales y Matemática (FCCNM), Universidad Nacional Federico Villarreal (UNFV), Código postal 15007, El Agustino, Lima, Perú.

3 Programa de Pós-Graduação em Biologia Animal da Universidade Federal Rural do Rio de Janeiro, BR 465, Km 7, CEP 23890-000, Seropédica, Rio de Janeiro, Brazil.

4 Departamento de Parasitologia Animal, Universidade Federal Rural do Rio de Janeiro, Seropédica, RJ, Brazil, CEP 23851-970.

\section{Citación}

Carvalho-Azevedo A, Huancachoque EG, Cuellar I, Sáez GM, Cruces CL, Jhon D. Chero JD, Luque JL. 2021. New record of monogeneans (Platyhelminthes: Monogenea) infecting some marine fishes from the Peruvian coastal zone. Revista peruana de biología 28(3): e21125 (Agosto 2021). doi: http://dx.doi. org/10.15381/rpb.v28i3.21125

$\begin{array}{ll}\text { Presentado: } & 08 / 04 / 2021 \\ \text { Aceptado: } & 06 / 06 / 2021 \\ \text { Publicado online: } & 30 / 08 / 2021 \\ & \end{array}$

Editor:

Lidia Sánchez

\begin{abstract}
A parasitological survey searching monogeneans infesting marine fish was carried out during June 2018 and January 2020 from the coastal zone of Puerto Pizarro, Tumbes (northern Peru) and from the coastal zone of Chorrillos, Lima (central Peru). The gills, skin, nasal cavities, or branchial gill-cover of seven species were sampled. Ten monogenean species assigned to six families and nine genera were identified. The monogeneans Callorhynchocotyle callorhynchi (Manter, 1955); Capsala biparasiticum (Goto, 1894) Price, 1938; Euryhaliotrema sagmatum Kritsky \& Boeger, 2002; Listrocephalos kearni Bullard, Payne \&Braswell, 2004; Magniexcipula lamothei Bravo-Hollis, 1981; Nasicola klawei (Stunkard, 1962) Yamaguti, 1968; and Pseudorhabdosynochus anulus Violante-Gonzalez \& Rojas-Herrera, 2011 are registered for the first time in Peru. While Capsala gregalis (Wagner \& Carter, 1967) Chisholm \& Whittington, 2007; Heterocotyle margaritae Chero, Cruces, Sáez, Santos \& Luque, 2020; and Monocotyle luquei Chero, Cruces, lannacone, Sanchez, Minaya, Sáez \& Alvariño, 2016 have been previously registered in Peruvian waters, however, the region of Tumbes (northern Peru) represent a new locality record for these species.
\end{abstract}

\section{Resumen}

Durante junio de 2018 y enero de 2020 se realizó un levamiento parasitológico para buscar monogeneos que infectan peces marinos en la zona costera de Puerto Pizarro, departamento de Tumbes (norte de Perú) y en la zona costera de Chorrillos, departamento de Lima (centro de Perú). Se analizaron las branquias, la piel, las cavidades nasales o el opérculo de siete especies. Se identificaron diez especies de monogeneos, asignadas a seis familias y nueve géneros. Los monogeneos Callorhynchocotyle callorhynchi (Manter, 1955); Capsala biparasitica (Goto, 1894) Price, 1938; Euryhaliotrema sagmatum Kritsky y Boeger, 2002; Listrocephalos kearni Bullard, Payne y Braswell, 2004; Magniexcipula lamothei Bravo-Hollis, 1981; Nasicola klawei (Stunkard, 1962) Yamaguti, 1968; y Pseudorhabdosynochus anulus Violante-Gonzalez \& Rojas-Herrera, 2011 son registrados por primera vez en Perú. Mientras que, Capsala gregalis (Wagner y Carter, 1967) Chisholm y Whittington, 2007; Heterocotyle margaritae Chero, Cruces, Sáez, Santos \& Luque, 2020; y Monocotyle luquei Chero, Cruces, lannacone, Sanchez, Minaya, Sáez \& Alvariño, 2016 han sido previamente registrados en aguas peruanas, sin embargo, la región de Tumbes (norte de Perú) representa un nuevo registro de localidad para estas especies.

Keywords:

Capsalidae; fish parasites; Hexabothriidae; Microcotylidae; Pacific Ocean.

Palabras clave:

Capsalidae; Hexabothriidae; Microcotylidae; Océano Pacífico; Parásitos de peces.

\section{Introduction}

Currently, 244 monogenean species have been described or reported infecting marine fish in South America. Of these, 96 species occur in Peru (Luque et al. 2016a, 2016b). Peru has a rich fauna of marine fish with approximately 1070 species, including Chondrichthyans and teleosts, distributed in 549 genera, 194 families and 39 orders (Chi- 
richigno \& Cornejo 2001). However, approximately 9\% of Peruvian marine fish have any parasitological study in monogeneans (Luque et al. 2016b). Thus, the current knowledge of the diversity of these fish parasites in Peru is still underestimated and many monogenean species, especially on poorly studied fish hosts, could be discovered (Cruces et al. 2020).

In this study, we inform about the monogenean records from fishes collected from coastal zone of Puerto Pizarro, norther Peru, and Chorrillos, central Peru, contributing to geographical distribution knowledge of 10 monogenean parasite species infecting marine fishes of the South American Pacific.

\section{Material and methods}

Fish were collected between June 2018 and January 2020 from the coastal zone of Puerto Pizarro, Tumbes region $\left(3^{\circ} 29^{\prime} \mathrm{S}, 80^{\circ} 24^{\prime} \mathrm{W}\right)$ (northern Peru) and from the coastal zone of Chorrillos, Lima region $\left(12^{\circ} 09^{\prime} \mathrm{S}\right.$, $77^{\circ} 01^{\prime} \mathrm{W}$ ) (central Peru), using gillnets and were dissected immediately after capture. Fish were identified according to Chirichigno and Vélez (1998).

Monogeneans were removed from gill filaments, skin, nasal cavities, or internal face of branchial gillcovers and transferred temporarily to dishes containing sea water. The monogeneans were cold fixed in $4 \%$ formaldehyde, under light cover glass pressure, stained with Semichon's carmine or Gomori's trichrome, dehydrated using a graded ethanol series, cleared with clove oil and mounted on glass slides using Canada balsam. Other specimens were mounted in Gray and Wess medium (Humason 1979) for the study of sclerotized structures. Specimens were analysed and measured using a compound Olympus ${ }^{\mathrm{TM}}$ BX51 light photomicroscope equipped with Nomarski Differential Interference Contrast (DIC) optics and drawings were made with the aid of a drawing tube. Unless otherwise stated, measurements are in micrometers, representing straight-line distances between extreme points of the structures measured and are expressed as the range followed by the mean and number (n) of specimens measured in parentheses. Body length represents the length of the body proper including the haptor.

The terms prevalence and mean intensity were used according to Bush et al. (1997). Vouchers of all helminth species were deposited in the Helminthological Collection of the Museo de Historia Natural de la Universidad Nacional Mayor de San Marcos (MUSM), Lima, Peru.

\section{Results}

We analysed 194 specimens of monogeneans recovered from 92 specimens of seven marine fish species. Detailed of morphological analysis made it possible to identify ten species belonging to nine genera and six families. The family and species of the monogeneans found in the present study, as well as measurements (only for species considered new records for Peru); taxonomic summaries containing the host, locality, site of infection, accession number of deposited specimens, and taxonomic comments for each monogenean species are presented below.

\author{
Taxonomy \\ Class Monogenea Van Beneden, 1858 \\ SUBCLASS MONOPISTHOCOTYLEA VAN BENEDEN, 1858 \\ FAMILY CAPSALIDAE BAIRD, 1853
}

\section{Capsala biparasiticum (Goto, 1894) Price, 1938}

\section{Figure 1}

Measurements: Body 7.65-10.45 (9.05; $\mathrm{n}=2) \mathrm{mm}$ long, maximum width 3.90-4.29 (4.09; $\mathrm{n}=2) \mathrm{mm}$. Sucker-like attachment organs 1.11-1.24 (1.17; $\mathrm{n}=2) \mathrm{mm}$ long, 0.89-1.01 (0.95; $\mathrm{n}=2) \mathrm{mm}$ wide. Pharynx 726-852 (789; $\mathrm{n}=2$ ) long, 896-968 (932; $\mathrm{n}=2$ ) wide. Haptor 2.68-3.29 (2.98; $\mathrm{n}=2$ ) mm long, 2.78-3.39 (3.09; $\mathrm{n}=2$ ) mm wide. Testes 150-164 (157; $\mathrm{n}=2$ ) long, 87-93 (90; $\mathrm{n}=2)$ wide. Cirrus sac 793-962 (878; $\mathrm{n}=2$ ) long, 177194 (186; $n=2)$ wide. Ovary 726-849 (788; $n=2)$ long, 878-915 (897; $n=2)$ wide.

Host: Thunnus albacares (Bonnaterre, 1788) (Perciformes: Scombridae), yellow-fin tuna.

Site in Host: Nasal cavity.

Locality: Puerto Pizarro, Tumbes Region, Peru (329'S $\left.80^{\circ} 24^{\prime} \mathrm{W}\right)$.

Voucher specimens deposited: 2 (MUSM 4720a-b).

Remarks: Capsala biparasiticum (Goto, 1894) Price, 1938 was initially described by Goto (1894) as Tristoma biparasitica Goto, 1894, collected from Thunnus albacores in Japan, later was transferred to the genus Caballerocotyla by Price (1938). Caballerocotyla biparasitica was transferred to genus Capsala Bosc, 1811 by Chisholm and Whittington (2007) based in the presence of a single row of multicuspid sclerites located on the dorsal edge of the body, a common genital pore that opens midway between the midline and the lateral margin of the body and a uterus that joins the MCO at approximately the posterior $1 / 3$ point. Two other species of $\mathrm{Ca}$ ballerocotyla, C. abidjani Bussieras \& Baudin-Laurencin, 1970 and C. neothunni (Yamaguti, 1968), both from $T$. albacores, were transferred to genus Capsala and considered synonymous of $C$. biparasiticum by having the aforementioned characteristics (see Chisholm \& Whittington 2007). Capsala biparasiticum was previously registered infecting the gills or oral cavity of T. albacares, T. maccoyii (Castelnau, 1872) and T. obesus (Lowe, 1839) in Japan, Gulf of Mexico, Hawaii, and Brazil. This is the first recorde of $C$. biparasiticum in Peru.

\section{Capsala gregalis (Wagner \& Carter, 1967) Chisholm \& Whittington, 2007}

\section{Figure 2}

Host: Sarda chiliensis (Cuvier, 1832) (Perciformes: Scombridae), Eastern Pacific bonito. 
Site in Host: Gill filaments.

Locality: Coastal zone of Puerto Pizarro, Tumbes Region, Peru $\left(3^{\circ} 29^{\prime} \mathrm{S} 80^{\circ} 24^{\prime} \mathrm{W}\right)$.

Voucher specimens deposited: 5 (MUSM 4721a-e).

Remarks: Capsala gregalis (Wagner \& Carter, 1967) Chisholm \& Whittington, 2007 was originally described by Wagner and Carter (1967) as Caballerocotyla gregalis based on specimens collected from Sarda chiliensis (Girard, 1858) in the North American Pacific Ocean of the United States. This species was characterized mainly by lacking dorsomarginal body sclerites (see Wagner \& Carter, 1967). However, Chisholm and Whittington (2007) examined the type specimens of Ca.gregalis and noticed the presence of a single row of small unicuspid dorsomarginal body sclerites. They transferred $\mathrm{Ca}$. gregalis to the genus Capsala. A capsalid species, Ca. australis Oliva, 1986 was described from the gills of $S$. chiliensis in Chile. This species was also reported from the same host in the central coast of Peru. Chisholm and Whittington (2007) synonymized $C a$. australis with $C$. gregalis because both species have a single row of unicuspid sclerites, haptoral accessory sclerites irregularly shaped, a common genital pore that opens close to the body margin and a similar distance from the left anterior attachment organ, and testes ranging in number between 27 and 35. This is the first record of Ca.gregalis in northern Peru.

Listrocephalos kearni Bullard, Payne \& Braswell, 2004

\section{Figure 3}

Measurements: Body 2.29-3.25 (2.79; $\mathrm{n}=4) \mathrm{mm}$ long, maximum width 0.82-0.99 (0.92; $\mathrm{n}=4) \mathrm{mm}$. Pharynx 186-264 (223; $n=4)$ long, 166-243 (206; $n=4)$ wide. Haptor $0.77-1.22(1.01 ; \mathrm{n}=4) \mathrm{mm}$ in diameter. Accessory sclerite 34-51 (45; $n=3)$ long. Anterior anchor 20-31 (25; $\mathrm{n}=3)$ long. Posterior anchor $15-26(22 ; \mathrm{n}=3)$ long. Hook 13-14 (14; $n=3)$ long. Testes 286-456 (372; $n=4)$ long, 199-347 (281; $n=4$ ) wide. Cirrus sac 279-398 (339; $n=$ 4) long, 142-220 (183; $n=4)$ wide. Gland of Goto 68-99 (79; $\mathrm{n}=4$ ) long, 62-95 (80; $\mathrm{n}=4$ ) wide. Ovary 131-225 $(158 ; n=4)$ long, $180-320(242 ; n=4)$ wide. Egg 176-213 (197; $n=3)$ long, 76-99 (85; $n=3)$ wide; filament of egg 99-126 (136; $n=3)$ long, 10-11 (11; $n=3)$ wide; Appendage of egg $57-83(73 ; n=3)$ in diameter.

Host: Hypanus dipterurus (Jordan and Gilbert, 1880) (Myliobatiformes: Dasyatidae), diamond stingray.

\section{Site in Host: skin.}

Locality: Coastal zone of Chorrillos, Lima Region, Peru $\left(12^{\circ} 09^{\prime} \mathrm{S}, 77^{\circ} 01^{\prime} \mathrm{W}\right)$.

\section{Voucher specimens deposited: 1 (MUSM 3243).}

Remarks: Listrocephalos was created by Bullard et al. (2004) to accommodate two capsalid species from stingrays of the Gulf of California in Mexico, L. kearni Bullard, Payne and Braswell, 2004 from the diamond stingray, Hypanus dipterurus (Jordan \& Gilbert, 1880) and L. whittingtoni Bullard, Payne \& Braswell, 2004 from the long tail stingray, H. longus (Garman, 1880) (Bullard et al. 2004). Currently, Listrocephalos contains four valid species, namely L. corona (Hargis, 1955), L. guberleti (Caballero \& Bravo-Hollis, 1962), L. kearni and L. whittingtoni. All of them described from stingrays (Dasyatidae, Urolophidae and Urotrygonidae) from the Pacific and Atlantic Oceans (Bullard et al. 2004, Kearn \& Whittington 2005, Mendoza-Garfias et al. 2017, Merlo-Serna \& GarcíaPrieto 2016, Perkins et al. 2009, Whittington 2010). The specimens studied herein were closer to these referred by Bullard et al. (2004) in the original description of $L$. kearni, but some characters appear to be smaller. This species differs from its congeners mainly in terms of the vas deferens, which have a convoluted proximal portion occupying the space between the oötype and ovary (Bullard et al. 2004). Our finding of L. kearni parasitizing $H$. dipterurus on the coast of Peru extend the geographic distribution of the species from the original.

Locality: Gulf of California, Mexico in the Pacific Ocean.

\section{Nasicola klawei (Stunkard, 1962) Yamaguti, 1968}

\section{Figure 4}

Measurements: Body oval, 10-14.4 (13.1; $\mathrm{n}=10)$ mm long, 9.2-12.92 (11.46; $\mathrm{n}=10) \mathrm{mm}$ in maximum width; dorsolateral margin of body with two irregular rows of sclerites: outer row with 214-399 (305; n=5) large spines and inner row with $35-52(40 ; n=5)$ small spines. Haptor circular, $73.25-3.78$ (3.57; $\mathrm{n}=10$ ) $\mathrm{mm}$ in diameter, with one central and seven peripheral loculi; marginal membrane delicate; accessory sclerites small, 27-43 (37; $n=5)$ long, with short and bifid shaft. Suckerlike attachment organs 450-725 (608; $n=10)$ long, 375750 (639; $n=10$ ) wide. Pharynx 1.05-1.63 (1.39; n=9) mm long; anterior region 1.05-1.50 (1.29; $\mathrm{n}=10) \mathrm{mm}$ wide; posterior region $0.85-1.18(1,09 ; \mathrm{n}=10) \mathrm{mm}$ wide. Cirrus sac 700-900 (784; $n=7$ ) long. Testes 29 in number, $120-230$ (176; $n=35)$ long. Gland of Goto 22 in number, 210-550 (316; n=34) long. Ovary 0.85-1.60 (1.34; $n=9)$ mm long, 0.870-1.65 (1.33; $\mathrm{n}=9) \mathrm{mm}$ wide.

Host: Thunnus albacares (Bonnaterre, 1788) (Perciformes: Scombridae), yellow-fin tuna.

\section{Site in Host: Nasal cavity.}

Locality: Coastal zone of Puerto Pizarro, Tumbes Region, Peru $\left(3^{\circ} 29^{\prime} \mathrm{S} 80^{\circ} 24^{\prime} \mathrm{W}\right)$.

\section{Voucher specimens deposited: 13 (MUSM 4722a-m).}

Remarks: This species was initially described as a member of the genus Caballerocotyla by Stunkard (1962) based in specimens collected from nasal cavity of T. albacores in the Pacific Ocean. Later, Yamaguti (1968) transferred Ca. klawei to genus Nasicola Yamaguti, 1968, as $N$. klawei (Stunkard, 1962) Yamaguti, 1968. Currently, three valid species of Nasicola are recognized, namely N. brasiliensis Kohn, Baptista-Farias, dos Santos \& Gibson, 2004; N. hogansi Wheeler \& Beverly-Burton, 1987, and N. klawei, all of them described or reported from tunas in the Atlan- 
tic and Pacific Oceans (Lopes et al. 2016). Nasicola klawei was redescribed by Kohn et al. (2004) and has been reported infecting the nasal cavity of T. albacores in México and Brazil (Bullard et al. 2011, Justo \& Kohn 2015, Kohn et al. 2004) and T. obesus in Hawai (Wheelery \& Beverley-Burton 1987). Morphometric characteristics of the specimens studied in the present work corresponds to the previous data obtained by Lamothe (1997) and Kohn et al. (2004) for $\mathrm{N}$. klawei, but the size of body appears to be bigger. $\mathrm{Na}$ sicola klawei is considered a new record for Peru.

\section{FAMILY DACTYLOGYRIDAE}

\section{Euryhaliotrema sagmatum Kritsky \& Boeger, 2002}

Measurements: Body elongate, 764 long; greatest width 255 usually at level of testis. Pharynx 78 in greatest width. Haptor 99 long; 61 wide. Ventral anchor 25 long, base 19 wide. Dorsal anchor 20 long, base 17 wide. Ventral bar 30 long. Dorsal bar 36 long. Hook 12 long. MCO 89 long. Accessory piece 47 long. Testis 125 long, 68 wide. Ovary 152 long, 46 wide.

Host: Umbrina xanti Gill, 1862 (Perciformes: Sciaenidae), polla drum.

Site in Host: Gill filaments.

Locality: Coastal zone of Puerto Pizarro, Tumbes Region, Peru $\left(3^{\circ} 29^{\prime} \mathrm{S} 80^{\circ} 24^{\prime} \mathrm{W}\right)$.

\section{Voucher specimens deposited: 1 (MUSM 4723).}

Remarks: A single specimen of Euryhaliotrema sagmatum Kritsky \& Boeger, 2002 was collected from the gills of the polla drum Umbrina xanti Gill, 1862 (Perciformes: Sciaenidae). Morphological comparison of the present specimen with the original description of $E$. sagmatum provided by Kritsky and Boeger (2002) did not reveal any differences. Euryhaliotrema sagmatum has also been registered infecting the gill of $U$. xanti in Mexico (Kritsky \& Boeger 2002). This is the first record of $E$. sagmatum in the Peruvian coast.

\section{FAMILY DIPLECTANIDAE}

\section{Pseudorhabdosynochus anulus Violante-Gonzalez \&} Rojas-Herrera, 2011

Measurements: Body elongate, 378 long; greatest width 97 usually at level of testis. Pharynx 23 in greatest width. Haptor 99 long; 128 wide. Squamodisc 69 long; 65 wide. Ventral anchor 37 long, base 19 wide. Dorsal anchor 32 long, base 12 wide. Ventral bar 68 long. Dorsal bar 47 long. Hook 11 long. MCO 92 long. Testis 46 long, 44 wide. Ovary 30 long, 41 wide.

Host: Epinephelus labriformis (Jenyns, 1840) (Perciformes: Serranidae), starry grouper

Site in Host: Gill filaments.

Locality: Coastal zone of Puerto Pizarro, Tumbes Region, Peru $\left(3^{\circ} 29^{\prime} \mathrm{S} 80^{\circ} 24^{\prime} \mathrm{W}\right)$.

Voucher specimens deposited: 1 (MUSM 4724).
Remarks: The only diplectanid specimen collected from the gills of the starry grouper Epinephelus labriformis (Jenyns, 1840) was identified as Pseudorhabdosynochus anulus Violante-Gonzalez \& Rojas-Herrera, 2011 by having a $\mathrm{C}$-shaped sclerotized vaginal canal and by having a ring-like internal structure in the distal extremity of the male copulatory organ (Mendoza-Franco et al., 2011). Pseudorhabdosynochus anulus has also been registered infecting the gill of E. labriformis in Mexico and Panama (Mendoza-Franco et al. 2011). This is the first record of E. sagmatum in the Peruvian coast.

\section{FAMILY MONOCOTYLIDAE}

Heterocotyle margaritae Chero, Cruces, Sáez, Santos \& Luque, 2020

Figure 5

Host: Hypanus dipterurus (Jordan and Gilbert, 1880) (Myliobatiformes: Dasyatidae), diamond stingray.

Site in Host: Gill filaments.

Locality: Coastal zone of Puerto Pizarro, Tumbes Region, Peru (329'S 80²4'W).

Voucher specimens deposited: 3 (MUSM 4725a-c).

Remarks: This species was recently described parasitizing $H$. dipterurus from Chorrillos, Lima Region (central Peru) (Chero et al. 2020). Heterocotyle margaritae is typified by its male copulatory organ, which is funnel-shaped, spatulate distally with lateral folds and by its club-shaped accessory piece (Chero et al. 2020). In addition, this species is characterized by having a haptor with one central and eight peripheral loculi, $1 / 2 / 3$ sinuous ridge arrangement and a vagina sclerotized. These findings extend the distribution to a new locality in northern Peru.

Monocotyle luquei Chero, Cruces, Iannacone, Sanchez, Minaya, Sáez \& Alvariño, 2016

Figure 6

Host: Hypanus dipterurus (Jordan and Gilbert, 1880) (Myliobatiformes: Dasyatidae), diamond stingray.

Site in Host: Gill filaments.

Locality: Coastal zone of Chorrillos, Lima Region, Peru $\left(12^{\circ} 09^{\prime} \mathrm{S}, 77^{\circ} 01^{\prime} \mathrm{W}\right)$; Coastal zone of Puerto Pizarro, Tumbes Region, Peru (3⒉'S 80²4'W).

Voucher specimens deposited: 3 (MUSM 4726a-c).

Remarks: Monocotyle luquei Chero, Cruces, Iannacone, Sanchez, Minaya, Sáez \& Alvariño, 2016 was described on Hy. dipterurus from Chorrillos, Lima (central Peru) (Chero et al. 2016). Morphometric characteristics of the specimens studied in the present work corresponds to the previous data obtained by Chero et al. (2016) for M. luquei. This species is characterized by having a male copulatory organ with 1-2 distal loops; a haptor with one central and eight peripheral loculi with haptoral sclerites of four types (bicuspid, tricuspid, qua- 
dricuspid and pentacuspid); marginal haptoral papillae with five sclerites and a sclerotized vagina. The specimens of $M$. luquei on the north coast of Peru extend the geographic distribution of the species from the original locality (central Peru).

\section{SubCLASS Polyopisthocotylea VAN BENEDEN, 1858}

FAMILY HEXABOTHRIIDAE PRICE, 1942

\section{Callorhynchocotyle callorhynchi (Manter, 1955) Boeger, Kritsky \& Pereira, 1989}

\section{Figure 7}

Measurements: Body elongate, 5.75-11.25 (8.16; n = 9) $\mathrm{mm}$ long, 0.55-1.30 (0.98; $\mathrm{n}=9) \mathrm{mm}$ wide at level of ovary. Oral sucker subterminal, 250-380 (297; n = 7) long, 300-430 (354; $\mathrm{n}=7$ ) wide. Pharynx medial, 75-93 (85; $\mathrm{n}=7$ ) long, 70-98 (84; $\mathrm{n}=7$ ) wide. Haptor asymmetrical, 1.10-2.63 (1.61; $\mathrm{n}=7$ ) mm long, 1.50-3.01 (2.34; $\mathrm{n}=7) \mathrm{mm}$ wide. Haptoral sucker sclerite 1 and 1', 290$440(365 ; \mathrm{n}=8)$ in maximum length, $40-50(41 ; \mathrm{n}=8)$ wide; haptoral sucker sclerite 2 and 2', 330-500 (398; n $=8)$ in maximum length, $40-55(42 ; \mathrm{n}=8)$ wide; haptoral sucker sclerite 3 and 3', 370-550 (462; $\mathrm{n}=9$ ) in maximum length, 40-70 (53; $n=9)$ wide. Appendix armed (= having anchors), 270-500 (341; $\mathrm{n}=8$ ) long, 270-500 (341; $\mathrm{n}=7$ ) wide. Anchors (= hamuli) 50-63 (59; $\mathrm{n}=9$ ) long, 8-28 (16; $n=6)$ wide.

Host: Callorhinchus callorynchus (Linnaeus, 1758) (Chimaeriformes: Callorhinchidae), plownose chimaera or elefant-fish.

\section{Site in Host: Gill filaments.}

Locality: Coastal zone of Chorrillos, Lima Region, Peru $\left(12^{\circ} 09^{\prime} \mathrm{S}, 77^{\circ} 01^{\prime} \mathrm{W}\right)$.

\section{Voucher specimens deposited: 9 (MUSM 4727a-i).}

Remarks: Callorhynchocotyle was proposed by $\mathrm{Su}-$ riano and Incorvaia (1982) to accommodate Callorhynchocotyle marplatensis Suriano and Incorvaia, 1982 using specimens collected from the gills of the American elephantfish, Callorhinchus callorynchus (Linnaeus, 1758) in Argentina (Atlantic Ocean) (Boeger et al. 1989, Boeger \& Kritsky 1989, Suriano \& Incorvaia 1982, Vaughan \& Christison 2012). To date, five valid species of Callorhynchocotyle are recognized, namely C. amatoi Boeger, Kritsky \& Pereira, 1989; C. callorhynchi (Manter, 1955); C. hydrolagi Beverley-Burton, Chisholm \& Last, 1990; C. marplatensis and $C$. sagamiensis Kitamura, Ogawa, Taniuchu \& Hirose, 2006 (Vaughan \& Christison 2012), all of them described from chimaerid and callorhinchid fish in the Atlantic and Pacific Oceans (Kitamura et al. 2006, Vaughan \& Christison 2012). Callorhynchocotyle callorhynchi was initially described as Squalonchocotyle callorhynchi by Manter (1955) from the cape elephantfish, $C$. capensis Duméril, 1865 and the ghost shark, $C$. milii Bory de Saint-Vincent, 1823 in South Africa and New Zealand, respectively. Later, Dillon and Hargis (1968) transferred S. callorhynchi to genus Erpocotyle. Subsequently, Boeger et al. (1989) redescribed and transferred E. callorhynchi within the genus Callorhynchocotyle, based on the absence of a glandular region of the cirrus, presence of a bulbous distal cirrus, a dorsal instead of terminal haptoral appendix and a terminal glandulomuscular portion of vagina. The specimens studied here are in accordance with the description given by Vaughan and Christison (2012) and Poddubnaya et al. (2015) for C. Callorhynchocotyle. The taxonomic characters of $C$. callorhynchi were performed by Manter (1955), Boeger et al. (1989), BeverleyBurton and Chisholm (1990) and Vaughan and Christison (2012), revealing the presence of a papillate surface in the lumen of the haptoral suckers. However, Poddubnaya et al. (2015) show for first time the presence of spines and not papillae on the inner surface of the suckers of $C$. callorhynchi. In South America, C. callorhynchocotyle has been registered on the gill filaments of $C$. callorynchus off the coast of Chile and Falkland-Patagonian Region (Cohen et al. 2013). In Peru, only C. marplatensis has been registered on the gill filaments of $C$. callorynchus (Luque et al. 2016). Callorhynchocotyle callorhynchi is a new record to the Peruvian Pacific Ocean. The record of $C$. callorhynchi in the coast of Peru is not a surprise because the geographical distribution of the fish host includes the Pacific and Atlantic coast of South America.

\section{FAMILY MICROCOTYLIDAE PRICE, 1942}

\section{Magniexcipula lamothei Bravo-Hollis, 1981}

Measurements: Body fusiform, 2.27-5.70 (4.17; n =10) $\mathrm{mm}$ long, $0.29-0.58(0.46 ; \mathrm{n}=10) \mathrm{mm}$ in maximum width. Clamp measurements: anterior most clamps 5159 (55; $n=3$ ) long; medial clamps 48-50 (49; $n=3$ ) long; terminal clamps 38-50 (42; $n=5)$ long. Buccal suckers septate, 35-77 (57; $\mathrm{n}=9$ ) long, 49-90 (65; $\mathrm{n}=8$ ) wide. Pharynx 27-39 (34; $\mathrm{n}=10$ ) long, 33-36 (35; $\mathrm{n}=10$ ) wide. Testes 17-18 in number. Genital atrium unarmed, distant 307-457 (361; n = 9) from anterior end. Cirrus armed with two sclerotized rods and numerous small sigmoid spines; rods 78-88 (856; $n=9$ ) long. Vitelline follicles 307-457 (361; $\mathrm{n}=8)$ from anterior end. Vaginal pore 386-442 (406; $n=4$ ) from anterior end. Egg 157$220(195 ; n=3)$ long, 62-80 (70; $n=3)$ wide, with single long filament at abopercular pole.

Host: Calamus brachysomus (Lockington, 1880) (Perciformes: Sparidae), Pacific porgy.

Site of infection: Gill filaments.

Locality: Coastal zone of Puerto Pizarro, Tumbes Region, Peru $\left(3^{\circ} 29^{\prime} \mathrm{S} 80^{\circ} 24^{\prime} \mathrm{W}\right)$.

Voucher specimens deposited: 6 voucher specimens (MUSM 4728a-f).

Remarks: Magniexcipula is a monotypic genus and was erected by Bravo-Hollis (1981) to accommodate a microcotylid species, Magniexcipula lamothei Bravo-Hollis, 1981, from the gills of the Pacific porgy, Calamus brachysomus (Lockington, 1880) (Perciformes: Sparidae) in Mexico. This genus is characterized by having a welldeveloped vitelline-seminal receptacle and by the great complexity of the copulatory organ and genital atrium. 
Morphometrical comparison of the present specimens with the original description of $M$. lamothei provided by Bravo-Hollis (1981) did not reveal any differences. Magniexcipula lamothei has also been registered infecting the gill filaments of the spotted head sargo, Genyatremus dovii (Günther, 1864) (Perciformes: Haemulidae) in Mexico
(Mendoza-Garfias \& Pérez-Ponce de León 1998). This is the first record of M. lamothei in the Peruvian coast. The presence of $M$. lamothei in the South American Pacific might be a result from the geographical distribution of the host ( $C$. brachysomus), who is distributed from the coast of the Southern California (USA) to Peru.
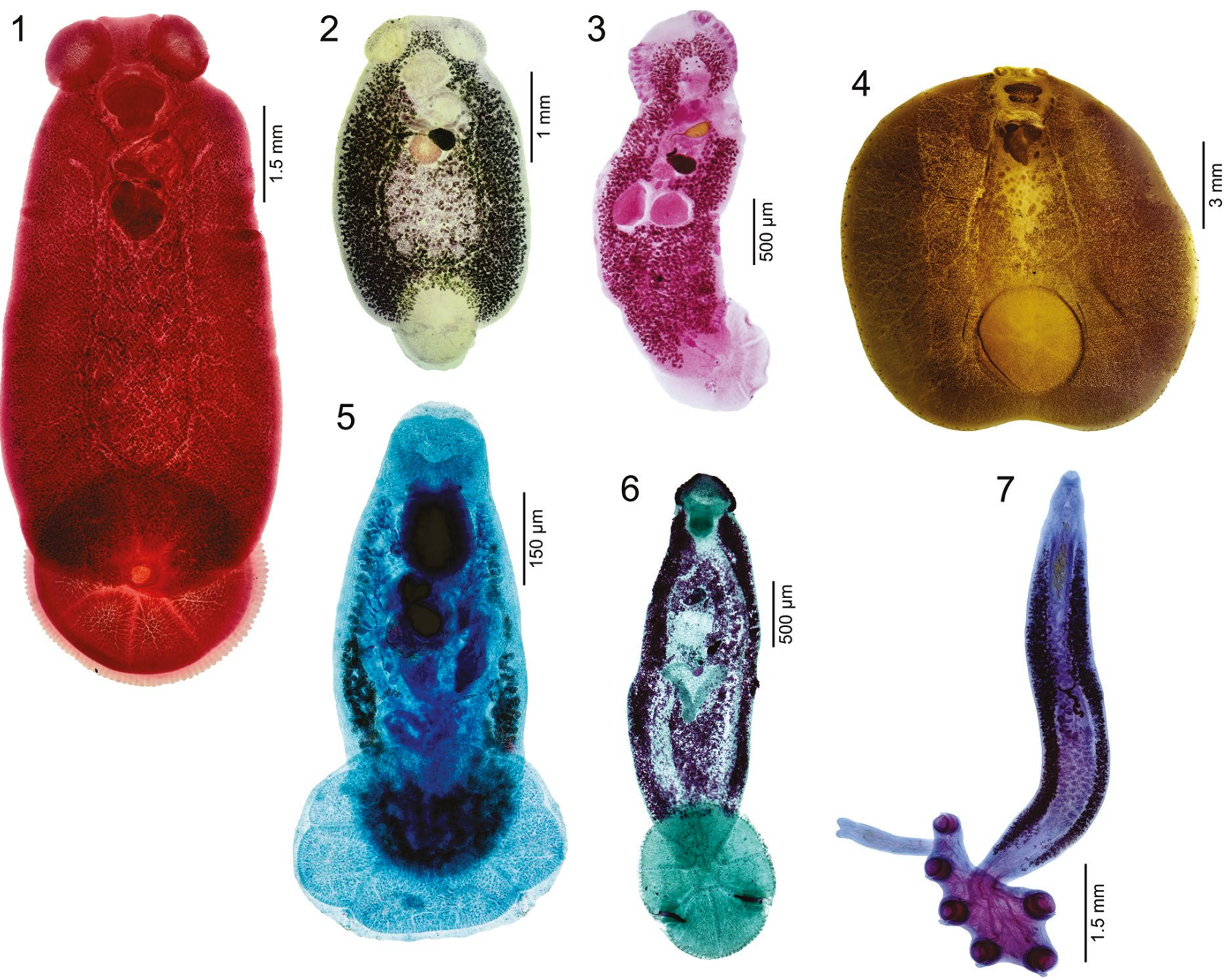

Figure 1-7. Monogeneans infecting some marine fishes from Peruvian coastal zone. 1. Capsala biparasiticum (Goto, 1894) Price, 1938 from Thunnus albacares. 2. Capsala gregalis (Wagner \& Carter, 1967) Chisholm \& Whittington, 2007 from Sarda chiliensis. 3. Listrocephalos kearni Bullard, Payne \& Braswell, 2004 from Hypanus dipterurus. 4. Nasicola klawei (Stunkard, 1962) Yamaguti, 1968 from Thunnus albacares. 5. Heterocotyle margaritae Chero, Cruces, Sáez, Santos \& Luque, 2020 from Hypanus dipterurus. 6. Monocotyle luquei Chero, Cruces, lannacone, Sanchez, Minaya, Sáez \& Alvariño, 2016 from Hypanus dipterurus. 7. Callorhynchocotyle callorhynchi (Manter, 1955) Boeger, Kritsky \& Pereira, 1989 from Callorhinchus callorynchus.

\section{Discussion}

In the present study, we identified ten monogenean species, assigned to six families (Capsalidae, Dactylogyridae, Diplectanidae, Hexabothriidae, Microcotylidae and Monocotylidae) and nine genera (Callorhynchocotyle, Capsala, Euryhaliotrema, Heterocotyle, Listrocephalos, Magniexcipula, Monocotyle, Nasicola and Pseudorhabdosynochus), on marine fish belonging to six families (Callorhinchidae, Dasyatidae, Sciaenidae, Scombridae, Serranidae and Sparidae) from Peru. The monogeneans C. callorhynchi, C. biparasiticum, E. sagmatum, L. kearni,
M. lamothei, N. klawei and P. annulus are registered for the first time in Peru. While C. gregalis, H. margaritae and $M$. luquei have been previously registered in Peruvian waters, however, the region of Tumbes (northern Peru) represents a new locality record for these species.

Luque et al. (2016) listed six species representing four genera of monogeneans from three marine chondrichthyans in Peru, a Callorhynchocotyle species (Hexabothriidae) from C. callorynchus, two Rhinobatonchocotyle species (Hexabothriidae) from Pseudobatos planiceps Garman, 1880 (Rhinopristiformes: Rhino- 
batidae), a Loimos species (Loimoidae) from Mustelus dorsalis Gill, 1864 (Triakidae) and two Anoplocotyloides species (Monocotylidae) from $P$. planiceps. Currently, the number of species of monogeneans that infect these fishes in Peru has increased to 10 (Chero et al. 2016, 2018a, 2018b, 2019), with Heterocotyle margaritae Chero, Cruces, Sáez, Santos \& Luque, 2020 (Monocotylidae) being the last species to be described (Chero et al. 2020). The two species, C. callorhynchi and L. kearni, registered here increases the number of monogeneans that infect marine chondrichthyans to 12 , which are relatively poorly studied fish hosts. Since the chondrichthyan fauna of Peru is rich and consists of 115 species (66 sharks; 43 batoids; 6 chimaeras), it is possible that many monogeneans are not registered in Peru.

The Hexabothriidae Price, 1942 (Monogenea) include species that infect the buccal cavity, gill arches or respiratory surfaces of chondrichthyan fishes (sharks, stingrays and chimaeras) (Chero et al. 2018a, 2019). These species are characterized by having a haptor with three pairs of sucker complexes, each of which are armed with a large, hooked sclerites; and by having a haptoral appendix, which bears a pair of small suckers at its distal end (Boeger \& Kritsky 1989, Chero et al. 2019). Three hexabothriid species have been described or recorded infecting the gills of marine elasmobranchs in Peru: $\mathrm{Ca}$. marplatensis; Hypanocotyle bullardi Chero, Cruces, Sáez, Camargo, Santos \& Luque, 2018 and Rhinobatonchocotyle pacifica Oliva \& Luque, 1995. An additional species, Rhinobatonchocotyle cyclovaginatus Doran, 1953 was also reported infecting the gills of $P$. planiceps in Peru (Tantaleán et al. 1998). However, according to Chero et al. (2019) this was an identification error. The species of Callorhynchocotyle registered here increases the number of hexabothriids species to four.

Regard to capsalids, four species have been registered infecting the gills of five marine fish in Peru: $C$. gregalis from $S$. chiliensis, Encotyllabe antofagastensis Sepúlveda, González \& Oliva, 2014 from Anisotremus scapularis (Tschudi, 1846) (Haemulidae); E. callaoensis Tantaleán, 1974 from Paralonchurus peruanus (Steindachner, 1875) (Sciaenidae) and Sciaena deliciosa (Tschudi, 1846) (Sciaenidae); Macrophyllida antarctica (Hughes, 1928) Johnston, 1930 from Cheilodactylus variegatus Valenciennes, 1833 (Cheilodactylidae) (Luque et al. 2016). Listrocephalos kearni is the first capsalid monogenean registered from a marine chondrichthyan in Peru.

At present, eight microcotylid species have been registered in Peru, seven of them infecting the gills of marine perciforms (Luque et. al. 2016). This is the first record of a microcotylid species infecting sparid fish from Peru.

\section{Literature cited}

Beverley-Burton M, Chisholm LA. 1990. Callorhynchocotyle hydrolagi n. sp. (Monogenea: Hexabothriidae) from Hydrolagus ogilbyi (Chimaeriformes: Chimaeridae) in the South Pacific. Systematic Parasitology 16: 241246. https://doi.org/10.1007/BF00009151
Boeger WA, Kritsky DC. 1989. Phylogeny, coevolution, and revision of the Hexabothriidae Price, 1942 (Monogenea). International Journal for Parasitology 19: 425-440. https://doi.org/10.1016/0020-7519(89)90099-4

Boeger WA, Kritsky DC, Pereira JJr. 1989. Neotropical Monogenea. 14. Revision of Callorhynchocotyle Suriano and Incorvaia, 1982 (Hexabothriidae) with the description of C. amatoi. Proceedings of the Biological Society of Washington 102: 264-271.

Bravo-Hollis M. 1981. Helmintos de peces del pacifico mexicano. XXXV. Descripción de un género nuevo de la subfamilia Microcotylinae Monticelli, 1892. Anales del Instituto de Biologia Universidad Nacional Autónoma de México, Serie Zoologia 51: 29-40.

Bullard SA, Payne RR, Braswell JS. 2004. New genus with two new species of capsalid monogeneans from dasyatids in the gulf of California. Journal of Parasitology 90: 1412-1427. https://doi.org/10.1645/GE-304R

Bullard SA, Frasca SJr, Benz G W. 2011. Gill Lesions Associated with Erpocotyle tiburonis (Monogenea: Hexabothriidae) on Wild and Aquarium-Held Bonnethead Sharks (Sphyrna tiburo). American Society of Parasitologists 87: 972-977. https://doi.org/10.1645/00223395(2001)087[0972:GLAWET]2.0.CO;2

Bullard SA, Womble MR, Maynard MK, Orélis-Ribeiro R, Arias CR. 2015. Skin lesions on yellowfin tuna Thunnus albacares from Gulf of Mexico outer continental shelf: Morphological, molecular, and histological diagnosis of infection by a capsalid monogenoid. Parasitology International 64: 609-621. https://doi.org/10.1016/j. parint.2015.08.005

Chisholm AL, Whittington ID. 2007. Review of the Capsalinae (Monogenea: Capsalidae). Zootaxa 1559: 11-30. https://doi.org/10.11646/zootaxa.1559.1.1

Chirichigno N, Cornejo RM. 2001. Catálogo comentado de los peces marinos del Perú. Publicación Especial del Instituto del Mar. Callao: Instituto del Mar del Perú, 314 p.

Chero JD, Cruces CL, Iannacone J, Sáez G, Sánchez L, Minaya D, Alvariño L. 2016. Monocotyle luquei n. sp. (Monogenea: Monocotylidae), from the gills of diamond stingray Dasyatis dipterura (Jordan and Gilbert, 1880) (Myliobatiformes: Dasyatidae), in the South Pacific. Acta Parasitologica 61: 713-719. https://doi. org10.1515/ap-2016-0100

Chero JD, Cruces CL, Sáez G, Camargo ACA, Santos CP, Luque JL. 2018a. Hypanocotyle bullardi n. gen. n. sp. (Monogenea: Hexabothriidae) from gill of the diamond stingray Hypanus dipterurus (Jordan et Gilbert) (Myliobatiformes: Dasyatidae) in the Southeastern Pacific Ocean off Peru. Parasitology International 67: 425-430. https://doi.org/10.1016/j.parint.2018.03.010

Chero JD, Cruces CL, Sáez G, Luque JL. 2018b. A new genus and species of the Dasybatotreminae Bychowsky, 1957 (Monogenea: Monocotylidae), parasitic on Hypanus dipterurus (Jordan \& Gilbert) (Myliobatiformes: Dasyatidae) in the Southeastern Pacific Ocean off Peru. Zootaxa 4527: 347-356. https://doi.org/10.11646/zootaxa.4527.3.4

Chero JD, Cruces CL, Sáez G, Portes Santos C, Luque JL. 2020. A new species of Heterocotyle (Monogenea: Monocotylidae), a gill parasite of the diamond stingray Hypanus dipterurus (Myliobatiformes: Dasyatidae) from the Peruvian coastal zone. Acta Parasitologica 65: 474481. https://doi.org/10.2478/s11686-020-00183-5

Cohen SC, Justo MC, Kohn A. 2013. South American Monogenoidea parasites of fishes, amphibians and reptiles. Oficina de Livros: Rio de Janeiro, 663 p. 
Cruces CL, Chero JD, Sáez G, Luque JL. 2020. A new genus and three new species of dactylogyrids (Monogenea), gill parasites of the threadfin bass, Pronotogrammus multifasciatus Gill (Perciformes: Serranidae) in the Southeastern Pacific Ocean off Peru. Systematic Parasitology 97: 121-131. https://doi.org/10.1007/ s11230-019-09900-9

Kitamura A, Ogawa A, Taniuchi T, Hirose H. 2006. Two new species of hexabothriid monogeneans from the ginzame Chimaera phantasma and shortspine spurdog Squalus mistukurii. Systematic Parasitology 65: 151-159. https://doi.org/10.1007/s11230-006-9046-6

Kohn A, Baptista-Farias MF, Dos Santos AL, Gibson DI. 2004. A new species of Nasicola Yamaguti, 1968 (Monogenea: Capsalidae) from the nasal cavities of Thunnnus obesus and a redescription of N. klawei (Stunkard, 1962) from T. albacares off Brazil. Systematic Parasitology 57: 51-58. https://doi.org/10.1023/ B:SYPA.0000010685.91891.5e

Kritsky DC, Boeger WA. 2002. Neotropical Monogenoidea. 41: New and previously described species of Dactylogyridae (Platyhelminthes) from the gills of marine and freshwater perciform fishes (Teleostei) with proposal of a new genus and a hypothesis on phylogeny. Zoosystema 24: 7-40.

Luque JL, Pereira FB, Alves PV, Oliva ME, Timi JT. 2016a. Helminth parasites of South American fishes: current status and characterization as a model for studies of biodiversity. Journal of Helminthology 8: 1-15. https:// doi.org/10.1017/S0022149X16000717

Luque JL, Cruces C, Chero J, Paschoal F, Alves PA, Silva A C, Sanchez L, Iannacone J. 2016b. Checklist of Metazoan parasites of fishes from Peru. Neotropical Helminthology 10: 301-375

Lamothe-Argumedo R. 1997. Nuevo arreglo taxonomico de la subfamilia Capsalinae (Monogenea: Capsalinae), clave para los géneros y dos combinaciones nuevas. Anales del Instituto de Biología, Universidad Nacional Autonóma de México 68: 207-223.

Manter HW. 1955. Two new monogenetic trematodes from elephant fishes (Callorhynchus) from South Africa and New Zealand. Essays in the natural sciences in honor of Captain Allan Hancock: 211-220. University of Southern California Press, Los Angeles.
Mendoza-Franco EF, Violante-González J, Herrera AAR. 2011. Six new and one previously described species of Pseudorhabdosynochus (Monogenoidea, Diplectanidae) infecting the gills of groupers (Perciformes, Serranidae) from the Pacific Coasts of Mexico and Panama. Journal of Parasitology 97: 20-35. https://doi. org/10.1645/GE-2716.1

Stunkard HW. 1962. Caballerocotyla klawei sp. n., a monogenetic trematode from the nasal capsule of Neothunnus macropterus. Journal of Parasitology 48: 883-890. https://doi.org/10.2307/3275120

Suriano DM, Incorvaia IS. 1982. Sistematica y biologia de Callorhynchocotyle marplatensis gen. et sp. nov. (Monogenea: Polyopisthocotylea) parasita de las branquias de Callorhynchus callorhinchus (Linne, 1758) Garman, 1904 (Pisces: Holocephali) de la región costera de Mar del Plata. Comunicaciones del Museu Argentino de ciencias naturales Bernardino Rivadavia e Instituto Nacional de Investigacion de las Ciencias Naturales. Parasitologia 2: 19-32.

Vaughan D, Christison K. 2012. Towards addressing the current state of confusion within the Hexabothriidae Price, 1942 (1908): Callorhynchocotyle Suriano \& Incorvaia, 1982 (Monogenea: Hexabothriidae) re-visited, with the preliminary evaluation of novel parameters for measuring haptoral armature of hexabothriids. Zootaxa, 3229: 1-34. https://doi.org/10.11646/zootaxa.3229.1.1

Yamaguti S. 1968. Monogenetic trematodes of Hawaiian fishes. Honolulu: University of Hawaii Press, $288 \mathrm{pp}$.

Wagner ED, Carter CE. 1997. Caballerocotyla gregalis sp. $n$. (Trematoda: Monogenea) from the Gills of Sarda lineolata (Girard). The Journal of Parasitology 53: 277-279.

Wheeler TA, Beverley-Burton M. 1987. Nasicola hogansi n. sp. (Monogenea: Capsalidae) from bluefin tuna, Thunnus thynnus (Osteichthyes: Scombridae), in the northwest Atlantic. Canadian Journal of Zoology 65: 1947-1950. https://doi.org/10.1139/z87-296

Whittington ID. 1998. Diversity "down under": monogeneans in the Antipodes (Australia) with a prediction of monogeneans biodiversity worldwide. International Journal for Parasitology 28: 1481-1493. https://doi. org/10.1016/S0020-7519(98)00064-2

\section{Agradecimientos / Acknowledgments:}

The authors are grateful to the following people who helped to the collection of fishes in Peru: Milagros K. Carrillo, Alexander Reyes and Cynthia E. Rodríguez, all from the National University Federico Villarreal (UNFV).

Conflicto de intereses / Competing interests:

The authors declare no conflict of interest.

Rol de los autores / Authors Roles:

$E G H, I C, G M Z, C L C$ and JDC have collected the specimens. ACA, $\mathrm{CLC}$, JDC and JLL analyzed the specimens. ACA and JDC wrote the paper. EGH, IC, GMZ, CLC, JDC and JLL reviewed and approved the manuscript.

Fuentes de financiamiento / Funding:

JDC and CLC were supported by a student fellowship from the Coordenação de Aperfeiçoamento de Pessoal do Ensino Superior, Brazil (CAPES)- Finance Code 001. JLL was supported by a Researcher fellowship from the Conselho Nacional de Desenvolvimento Científico e Tecnológico, Brazil (CNPq)

Aspectos éticos / legales; Ethics / legals:

Authors declare that they did not violate or omit ethical or legal norms in this research. 